http://dx.doi.org/10.18542/mri.v14i23.5778

\title{
SABERES E AUTONOMIA DOCENTE: UM DIÁLOGO ENTRE ELEMENTOS IMPRESCINDÍVEIS À FORMAÇÃO DO PROFESSOR
}

\author{
KNOWLEDGE AND TEACHING AUTONOMY: A DIALOGUE BETWEEN COMPREHENSIVE \\ ELEMENTS FOR TEACHER TRAINING \\ Nilce Pantoja do CARMO ${ }^{1}$ \\ Universidade Federal do Pará (UFPA) \\ Waldir Ferreira de ABREU ${ }^{2}$ \\ Universidade Federal do Pará (UFPA)
}

\begin{abstract}
Resumo: $O$ presente trabalho faz-se como um desdobramento da dissertação "Um rio no caminho: processos de escolarização de alunos ribeirinhos em contexto escolar urbano", apresentada em 2019 como critério avaliativo do título de Mestre em Educação ao Programa de PósGraduação em Educação (do Instituto de Ciências da Educação da Universidade Federal do Pará). Neste ínterim, "Saberes e autonomia docente: um diálogo entre elementos imprescindíveis à formação do professor", caracteriza-se como uma pesquisa bibliográfica, que objetiva compreender as relações peculiares aos saberes e à autonomia, discorrendo sobre como essa interação vem se constituindo no processo de formação do professor. Para tanto, buscou-se aporte nos trabalhos de Freire (1996), Contreras (2002) e Tardif (2014), autores que se debruçaram na abordagem de tais categorias (saberes e autonomia) vinculadas ao contexto formativo daqueles que estão afrente da prática educativa formal dos sujeitos. Os resultados do estudo apontam que a constituição da autonomia se associa diretamente ao aguçar dos saberes. Assim, a formação do professor deve considerar a relevância dos saberes como basilares ao fomento da autonomia docente.
\end{abstract}

Palavras-chave: Saberes; Autonomia; Formação do Professor.

\begin{abstract}
The present work unfolds from the dissertation "A river on the way: schooling processes of riverside students in an urban school context", presented in 2019 as an evaluation criterion for the title of Master in Education to the Graduate Program in Education (from the Institute of Educational Sciences of the Federal University of Pará). In the interim, "Teacher knowledge and autonomy: a dialogue between elements essential to teacher education", is characterized as bibliographic research, which aims to understand the peculiar relations to knowledge and autonomy, discussing how this interaction has been constituted in the teacher training process. Therefore, we sought theoretical contribution in the works of Freire (1996), Contreras (2002), and Tardif (2014), authors who focused on the apprehension and approach of such categories (knowledge and autonomy) linked to the formative context of those who are responsible for the formal educational practice of the subjects. The results of the study show that the constitution of autonomy is directly associated with the improvement of knowledge. Thus, teacher education must consider the relevance of knowledge as fundamental to the promotion of teacher autonomy
\end{abstract}

Keywords: Knowledge; Autonomy; Teacher Education

\footnotetext{
${ }^{1}$ Pedagoga. Docente da Secretaria Municipal de Educação e Cultura de Belém. Especialista em Educação Classe III da Secretaria Executiva de Educação do Pará. Especialista em Psicologia Educacional com Ênfase em Psicopedagogia Preventiva (UEPA). Mestra em Educação pelo Programa de Pós-Graduação em Educação do Instituto de Ciências da Educação (PPGED/ICED/UFPA).E-mail: jpnilce@yahoo.com.br

2 Pós-Doutor em Ciências da Educação, Doutor em Educação, Professor do Mestrado e Doutorado do Programa de PósGraduação em Educação do ICED/UFPA, Professor Associado II da UFPA, Líder do Grupo de Estudos e Pesquisas em Educação, Infância e Filosofia (GEPEIF/PPGED/ICED/UFPA/CNPq). E-mail: awaldir@ufpa.br
} 


\section{INTRODUÇÃO}

O artigo ora apresentado é resultante da pesquisa intitulada Um Rio no Caminho: processos de escolarização de alunos ribeirinhos em contexto escolar urbano, vinculada ao Programa de Pósgraduação em Educação, do Instituto de Ciências da Educação, da Universidade Federal do Pará, a qual debruçou-se sobre o processo de escolarização de alunos ilhéus (oriundos de regiões insulares do município de Belém), que se dirigem, diariamente, às escolas metropolitanas para terem acesso à educação formal.

O construto aborda a temática "Saberes e autonomia docente: um diálogo entre elementos imprescindíveis à formação do professor”, no escopo de compreender as relações peculiares aos saberes e à autonomia docente, discorrendo sobre como essa interação vem sendo vivenciada e analisada no processo de formação desse profissional, que possui importantes funções sociais. Sabese que o aguçar tanto dos saberes do professor quanto de sua autonomia são aspectos intimamente ligados, os quais necessitam de fomento e valorização para serem adequadamente desenvolvidos. Isso nos faz refletir acerca da necessidade de que ambos sejam considerados e enaltecidos desde a formação inicial do professor, prolongando-se por sua formação continuada e subsidiando o seu posicionamento responsável, crítico e reflexivo acerca da realidade que permeia sua atuação cidadã e profissional. Vê-se, assim, que o liame entre estas abordagens é parte consubstancial dos processos de formação do professor, o que também justifica essa discussão.

Objetivando propor um diálogo entre as duas categorias - saberes e autonomia docentes buscou-se o aporte teórico de estudiosos, que se inclinaram a compreender tais elementos como imprescidíveis à formação do professor. Assim, partindo-se da assertiva de que o aguçar da autonomia é um processo de desenvolvimento contínuo, buscou-se em Freire (1996) e Contreras (2002) o entendimento acerca dessa categoria, verificando-se que ela enviesa muito do que se espera de uma formação necessária na contemporaneidade. A formação do professor, por sua vez, é um dos campos de investigação que desperta mais interesse entre os estudiosos da área educacional. Dessa forma, apoiou-se nos estudos de Tardif (2014), para verificar como a formação de professores vem se dando nas últimas décadas, vislumbrando os saberes e a autonomia docentes como aspectos intrínsecos à formação consistente e coerente com as demandas da atual conjuntura social e educacional.

Diante disso, o trabalho se estrutura em três seções, que se integram e organizam em torno da formação do professor sob uma ótica de valorização de seus saberes e autonomia, despojando a compreeensão de como esses elementos, em permanente interação e construção, influenciam os 
modos de ser, estar e atuar desse profissional nos diversos contextos em que se insere. Na primeira seção, "Saberes docentes e autonomia profissional", evidencia-se a relevância dos saberes como basilares à constituição da autonomia docente. A segunda seção, "Saberes necessários à constituição da autonomia docente: algumas exigências cultivadas por Paulo Freire”, instrumentaliza-nos a refletir sobre as exigências necessárias à construção crítica da autonomia, sob a perspectiva de Freire, disposta no livro "Pedagogia da autonomia: saberes necessários à prática educativa". A terceira seção, “A autonomia como construção alicerçada na consciência crítica docente", enfatiza a consciência crítica como importante condição à construção da autonomia docente. Apresenta-se, nas considerações conclusivas, um sucinto apanhado dos aspectos mais relevantes do trabalho, reiterando a importância dialógica entre os elementos em discussão.

\section{SABERES DOCENTES E AUTONOMIA PROFISSIONAL}

A educação é um fenômeno complexo, cultural e histórico - produto do trabalho de seres humanos - e, como tal, inclina-se a responder aos desafios que diferentes contextos econômicos e sócio-políticos lhe apresentam. Ela retrata e reproduz a sociedade. Entretanto, também, é-lhe cobrada a capacidade de projetar a sociedade que se quer, vinculando-se profundamente ao processo civilizatório e humano. Esses atributos estão, sensivelmente, ligados à função docente, dirigindo ao professor a tarefa de responder às demandas contextuais vigentes. Dessa forma, cabe a este profissional (com seus saberes, formação e poder de decisão muitas vezes limitados), posicionar-se afrente dos desafios. Sua responsabilização para com as demandas sociais é tão séria quanto expressiva, necessitando que lhes sejam dados subsídios, igualmente sérios e expressivos, para que seu trabalho possa ser efetivamente desenvolvido.

Neste sentido, vê-se o relevante crescimento de pesquisas voltadas aos saberes e aos conhecimentos que se encontram na base e na natureza do trabalho docente. Para Ramalho e Nuñez (2014) a formação do professor faz-se como um itinerário organizado pedagogicamente para desenvolver conhecimentos, habilidades, atitudes e competências necessários a seu aguçar profissional, sendo fatores imprescindíveis ao avanço e à inovação da atividade de ensino como um todo. Os autores fundamentam a importância do professor e de seus saberes citando que:

[...] se reconhece que o professor é um profissional e que a atividade de ensino não é, simplesmente, de natureza técnica e sim uma profissão baseada em conhecimentos e saberes especializados. Ser um professor profissional exige um domínio de um repertório de conhecimentos que alia-se a outros fatores de natureza atitudinais e 
valorativas que permitem o exercício competente, a inovação e a criatividade de ensinar e educar, coerentes com as finalidades da Educação no contexto da sociedade e da escola do século XXI (RAMALHO E NUÑEZ, 2014, p. 12).

Sabe-se que no início deste século muitas expectativas são depositadas no sistema educacional, apresentando-se como definidor de indicadores do desenvolvimento social, cultural e econômico. É um momento marcado, em muitos países, por reformas educacionais voltadas à adequação da educação às exigências dos novos tempos e contextos, como a globalização das economias e os impactos das novas tecnologias no âmbito da formação dos professores e do cotidiano escolar. Nesta direção, Tardif (2014), constata que diversificados são os aspectos que influenciam e interferem na atuação docente, sendo que ao analisar a formação dos professores, nos últimos vinte anos, destaca a relevância das relações estabelecidas entre os conhecimentos produzidos pelos pesquisadores universitários das ciências da educação e os saberes mobilizados pelos professores no desenvolvimento de suas práticas laborais. Esses saberes - provenientes da experiência docente (saber-fazer) - ganham espaço nos estudos voltados à educação, que buscam compreender de que forma ocorre a profissionalização daqueles, cujas práticas estão no bojo das reformas educativas vigentes. Referindo-se aos saberes docentes, que servem de base ao trabalho no ambiente escolar, o autor expõe que:

Historicamente, essa questão está ligada à profissionalização do ensino e aos esforços feitos pelos pesquisadores em definir a natureza dos conhecimentos profissionais que servem de base ao magistério. Todavia, com o passar do tempo, ela foi-se alargando e se ramificando e deu origem à produções teóricas autônomas relativas, por exemplo, ao trabalho dos professores e à sua formação, ao pensamento dos professores e à sua história de vida, às relações entre a cultura escolar e a cultura dos professores, ao lugar dos saberes dos professores entre os saberes sociais, etc (TARDIF, 2014, p. 227-228).

Evidencia-se, que a ação cotidiana do professor faz-se como um terreno bastante fértil, o qual mobiliza sua expressão em diferentes situações. Nesta direção, Tardif valoriza a relação dos conhecimentos oriundos das universidades com os saberes extraídos e produzidos na prática docente. Seus estudos defendem a interação entre saber profissional e os saberes das ciências em educação, enfatizando que o saber do professor é um saber específico, que está relacionado com a pessoa e a identidade dele, com suas experiências e histórias, com as relações que travam com seus pares. Esse aspecto fica bastante evidente na citação a seguir:

[..] o saber dos professores é o saber deles e está relacionado com a pessoa e a identidade deles, com a sua experiência de vida e com a sua história profissional, com as suas relações com os alunos em sala de aula e com os outros atores escolares na escola, etc. Por isso, é necessário estudá-lo relacionando-o com esses elementos constitutivos do trabalho docente (TARDIF, 2014, p. 11). 
Constata-se que o processo de valorização dos saberes docentes coaduna com a construção e o fortalecimento de sua autonomia e identidade profissionais alicerçadas nas experiências cotidianas. Estas, consequentemente, expressam um saber-fazer que não pode ser desprezado. No entanto, cabenos neste contexto também a leitura de que o cenário que se apresenta caracteriza-se pela ênfase ao modelo da racionalidade técnica, que objetiva homogeneizar e regular as práticas educativas e seus sujeitos, tendo a produtividade como sua mola propulsora, o que acaba por revelar as intencionalidades do capitalismo neoliberal.

Contreras (2002) caracteriza a racionalidade técnica como um dos aspectos minimizadores da autonomia docente, uma vez que reduz os saberes profissionais à competência instrumental, visando a produtividade. Esse modelo de profissionalidade configura-se como uma atividade voltada ao alcance de resultados ou produtos predeterminados, no qual o professor torna-se um mero executor de atividades prévias e intencionalmente pensadas e elaboradas. $\mathrm{O}$ autor destaca que:

A ideia básica do modelo de racionalidade técnica é que a prática profissional consiste na solução instrumental de problemas mediante a aplicação de um conhecimento teórico e técnico, previamente disponível, que procede da pesquisa científica. É instrumental porque supõe a aplicação de técnicas e procedimentos que se justificam por sua capacidade para conseguir os efeitos ou resultados desejados (CONTRERAS, 2002, p.90-91).

Denota-se que o docente não deve se limitar à função de mero executor dos processos educativos, uma vez que tem o dever de elaborar, definir e reinterpretar os saberes a partir do que pensa, acredita e valora. Sua relação com os saberes é permeada de significância e complexidade. Nesta direção, Tardif expressa que:

[...] a relação dos docentes com os saberes não se reduz a uma função de transmissão dos conhecimentos já construídos. Sua prática integra diferentes saberes, com os quais o corpo docente mantém diferentes relações. Pode-se definir o saber docente como um saber plural, formado pelo amálgama, mais ou menos coerente, de saberes oriundos da formação profissional e de saberes disciplinares, curriculares e experienciais (TARDIF, 2014, p. 36).

A pluralidade dos saberes constitutivos da prática docente, evidencia a necessidade de que seja valorizada uma formação, igualmente, plural (oriunda da formação profissional e de saberes disciplinares, curriculares e experienciais), consistente e autônoma que se contraponha, com resistência, ao estabelecido, traduzindo-se em uma prática pedagógica sem reduzir-se a mesma. Sobre esse aspecto Freire (1996, p.14) enfatiza que “[...] reinsisto em que formar é muito mais do que puramente treinar o educando no desempenho de destrezas [...]”. A citação leva-nos a pensar na 
formação do aluno e na formação do próprio professor - que como aluno - deve compreender o ato educativo como algo que em muito extrapola o treino. $\mathrm{O}$ autor vai além, reafirmando a correlação entre formação e educação, quando cita:

[...] transformar a experiência educativa em puro treinamento técnico é amesquinhar o que há de fundamentalmente humano no exercício educativo: o seu caráter formador. Se se respeita a natureza do ser humano, o ensino do conteúdo não pode dar-se alheio à formação moral do educando. Educar é substantivamente formar (FREIRE, 1996, p. 33).

Freire cita a ideologia fatalista, como uma ação imobilizante, que insiste em nos convencer de que não podemos agir contra a realidade social vigente, a qual passa a ser naturalizada, ou seja, desprovida de razões/intenções histórico-culturais e, por tanto, cabe-nos aceitá-la. Essa ideologia, objetiva que a educação seja-lhe uma aliada imobilizadora, a partir da qual o treino técnico, na formação do sujeito, apresenta-se como um recurso pouco ou nada instigador da reflexão-ação acerca da realidade. Sobre esse aspecto Freire (1996, p. 20) enfatiza que "Do ponto de vista de tal ideologia, só há uma saída para a prática educativa: adaptar o educando a esta realidade que não pode ser mudada. O de que se precisa, por isso mesmo, é do treino técnico indispensável à adaptação do educando, à sua sobrevivência".

Contrapondo-se a essa ideologia fatalista, pensa-se no enaltecimento do docente como profissional responsável e comprometido, o que nos permite elaborar a noção de autonomia enquanto sério e constante exercício e uma forma de atuação e intervenção nos contextos concretos da prática - espaço/tempo onde/quando as decisões são produtos da compreensão e consideração da complexidade, ambiguidade e conflituosidade das situações. Compreende-se, dessa forma, a autonomia como uma construção que se vincula, intrinsicamente, aos saberes, à criticidade e à atuação docente, a partir das quais toma-se consciência da ação educativa alicerçada no desenvolvimento do fazer pedagógico articulado com a real qualidade da educação. Sobre esse aspecto Contreras evidencia que:

A consciência da complexidade e do conflito de interesses e valores é que faz com que as decisões autônomas tenham de ser entendidas como um exercício crítico de deliberação levando em conta diferentes pontos de vista. Já não falamos da autonomia como uma capacidade ou atributo que se possui, mas de uma construção permanente em uma prática de relações. Enquanto qualidade em uma relação, a autonomia se atualiza e se configura no mesmo intercâmbio que a relação se constitui (CONTRERAS, 2002, p. 197).

Vislumbra-se, nesta perspectiva, que a autonomia se faz como uma construção que não sugere o isolamento e/ou a capacidade de decisão hierarquizada e individualizada, mas que deve ser 
compreendida como a forma dialógica de se conduzir profissional e socialmente, refletindo os modos desejáveis de relações que se cultiva. Para Contreras (2002, p. 197) “[...] a autonomia não é uma definição das características dos indivíduos, mas a maneira com que estes se constituem pela forma de se relacionarem". Sendo que tal relação precisa ser reforçada por uma formação docente em que os saberes do professor façam-se como a base da sua autonomia, pois para que o professor exerça, de fato, a sua autonomia precisa mobilizar consistentes saberes docentes.

\section{SABERES NECESSÁRIOS À CONSTITUIÇÃO dA AUTONOMIA DOCENTE: ALGUMAS EXIGÊNCIAS CULTIVADAS POR PAULO FREIRE}

O cotidiano do professor, dentro e fora de sala de aula, é permeado por posturas de afirmação, reafirmação, negação, criação, problematização, resolução, conflito, enfrentamento e outros aspectos diante dos quais o diálogo, a escuta, a afetividade são saberes (entre tantos) que se fazem necessários à constituição de uma prática educativa favorecedora da qualidade de vida do educador, a partir da qual este reunirá condições para alcançar os objetivos que almeja junto a seus educandos. Esses elementos são, assim, de fundamental relevância na formação do educador, fomentando a sua autonomia.

Neste sentido, pensar a constituição da autonomia docente requer coerência com uma formação baseada no cultivo de saberes vinculados à prática educativa transformadora. Enfatiza-se, nesta perspectiva, o enaltecimento de uma pedagogia originária da ética, da estética e do respeito à dignidade e à autonomia (de educador e educando), compreendendo a prática docente enquanto dimensão social da formação humana.

Entende-se que a autonomia demanda do educador um exercício permanente, fundamentado na convivência respeitosa com seus alunos e na postura dialógica, curiosa e aberta que assume diante deles, instigando-lhes a assumirem-se enquanto sujeitos sócio-histórico-culturais do ato de conhecer.

Vale ressaltar que, inserido num contexto de desvalorização de seu trabalho, o professor precisa mobilizar, também permanentemente, sua reflexão crítica acerca das verdadeiras causas e consequências dessa desvalorização, vislumbrando meios e condições possíveis para subvertê-la, pois não há como se falar de autonomia sem considerar a leitura e ação crítica sobre a realidade. É necessário atentar, ainda, ao fato de que a autonomia pode ser usada, num discurso ideológico, para fomentar o individualismo e a competitividade. Nesta direção, Freire (1996) anuncia a solidariedade (enquanto compromisso histórico dos sujeitos) como uma das formas de luta contra a dominação hegemônica. 
Há inúmeras exigências necessárias ao ato de ensinar pressupostas por Freire (1996), sendo que com o intuito de desvelar os saberes fortalecedores da autonomia na prática docente, optou-se por dialogar acerca de algumas dessas exigências. São elas: "Ensinar exige rigorosidade metódica"; "Ensinar exige pesquisa"; "Ensinar exige criticidade"; "Ensinar exige reflexão crítica sobre a prática"; "Ensinar exige estética e ética"; "Ensinar exige a corporeificação das palavras pelo exemplo"; "Ensinar exige consciência do inacabamento"; "Ensinar exige respeito à autonomia do ser do educando"; "Ensinar exige bom senso"; "Ensinar exige apreensão da realidade"; "Ensinar exige conviç̧ão de que a mudança é possível"; "Ensinar exige comprometimento"; "Ensinar exige reconhecer que a educação é ideológica"; "Ensinar exige disponibilidade para o diálogo".

Ao expor que "Ensinar exige rigorosidade metódica", Freire enfatiza que o educador já teve ou tem experiência diante da produção de certos saberes, os quais não podem ser, simplesmente, transferidos ao educando (e por estes memorizados e repetidos). Há a necessidade de que o educador conheça o objeto a ser abordado e instrumentalize o educando a se transformar em sujeito da construção e da reconstrução do saber ensinado, o qual é apreendido em sua razão de ser, portanto, aprendido verdadeiramente. Não se preconiza, assim, apenas o ensino do conteúdo, mas fomenta-se no educando o aguçar do pensar certo como um movimento de conscientização e transformação. Neste sentido, Freire (1996, p. 28) mostra a relevância do papel docente frizando que "O professor que pensa certo deixa transparecer aos educandos que uma das bonitezas de nossa maneira de estar no mundo e com o mundo, como seres históricos, é a capacidade de, intervindo no mundo, conhecer o mundo". A intervenção, nessa perspectiva, é uma condição fundamental ao fomento da ação autônoma dos sujeitos.

Rigor também é necessário quando se pensa que "Ensinar exige pesquisa", pois não há como ensinar aquilo que não busco, procuro, pesquiso. Esses verbos são aplicados no tempo presente, indicando que estas ações não se esgotam, bem como não se esgota a renovação do conhecimento. Nesta direção, o professor fomenta sua autonomia quando debruça-se sobre ato de conhecer, bem como favorece o desenvolvimento da autonomia discente ao instigar sua curiosidade e levar-lhe ao aprofundamento dos saberes.

Concordamos com a assertiva de que "Ensinar exige criticidade" como um processo também resultante de procedimentos metodologicamente rigorosos que leva a superação da ingenuidade do saber. Ao aproximar-se, cada vez mais, do objeto ganha-se condições de se prescindir da curiosidade ingênua à curiosidade epistemológica, à inquietação indagadora, ao desvelamento e à procura de esclarecimentos. Esse processo, sem dúvida, é relevante à formação da autonomia docente oriunda, genericamente, da curiosidade e do saber crítico. 
Tal criticidade evidencia que não existe neutralidade na ação docente. Portanto, "Ensinar exige reflexão crítica sobre a prática", o que demanda constante movimento dialético entre o fazer e o pensar sobre fazer. A capacidade de mudança, de promoção de uma curiosidade ingênua à uma curiosidade epistemológica se fortalece quando o professor faz uma reflexão íntima de sua prática, assumindo como está e percebendo as razões desse estar sendo. Vê-se nesse movimento dinâmico de ação-reflexão-ação, um aliado ao fomento dos saberes práticos desencadeadores de maior autonomia docente. A esse respeito Freire elucida que:

[...] na formação permanente dos professores, o momento fundamental é o da reflexão crítica sobre a prática. É pensando criticamente a prática de hoje ou de ontem que se pode melhorar a próxima prática. O próprio discurso teórico, necessário à reflexão crítica, tem de ser de tal modo concreto que quase se confunda com a prática (FREIRE, 1996, p. 39).

Coerentemente com o citado por Freire, Tardif (2014) enfatiza que - na reflexão crítica acerca da prática dos professores - não se pode esquecer que seus saberes são saberes sociais, visto que seus objetos (de trabalho) são objetos sociais e os sujeitos com os quais trabalha são sujeitos sociais. Nesta perspectiva, ensinar demanda um saber agir com outros seres humanos, bem como requer a compreensão crítica de que o saber não é um conteúdo fechado em si, mas que se manifesta por meio de relações complexas entre professores e alunos.

As dimensões estética e ética permeiam todo o trabalho de Freire, sendo que tais dimensões configuram-se como saberes basilares ao ato educativo. Neste sentido, ratifica-se que "Ensinar exige estética e ética", valorizando o respeito à dignidade e à própria autonomia do educador e, igualmente, do educando. Valoriza-se, ainda, a prática docente movida esteticamente pela alegria, sem subjugar o sonho, o rigor e a seriedade nela envolvidos. A autonomia precisa ser fecundada num campo de rigorosidade ética: a ética inseparável da prática educativa - que condena a exploração do ser humano, que se manifesta contra toda discriminação de raça, gênero e classe - a qual devemos viver e testemunhar em nossas relações com os educandos e com os próprios conteúdos ensinados. Freire amplia tal ideia, expondo que:

[...] O preparo científico do professor ou da professora devem coincidir com sua retidão ética. É uma lástima qualquer descompasso entre aquele e esta. Formação científica, correção ética, respeito aos outros, coerência, capacidade de viver e de aprender com o diferente, não permitir que o nosso mal-estar pessoal ou a nossa antipatia com relação ao outro nos façam acusá-lo do que não fez. São obrigações a cujo cumprimento devemos humilde mas perseverantemente nos dedicar.

[...] Não podemos nos assumir como sujeitos da procura, da decisão, da ruptura, da opção, como sujeitos históricos, transformadores, a não ser assumindo-nos como sujeitos éticos (1996, p. 16-17). 
Advoga-se, assim como Freire, que decência e beleza (ética e estética) andam sempre juntas e que tais dimensões apresentam total coerência com a formação da autonomia docente à medida que esta precisa se fazer como um posicionamento pensado e responsável, pois como cita Freire (1996, p. 18) "É no domínio da decisão, da avaliação, da liberdade, da ruptura, da opção, que se instaura a necessidade da ética e se impõe a responsabilidade". A responsabilidade, citada pelo autor, remetenos à profundidade do pensar e agir, atos oriundos da adequada compreensão dos fatos.

Ao citar que "Ensinar exige a corporeificação das palavras pelo exemplo", Freire explicita que pensar certo é fazer certo, não podendo existir, por exemplo, distância entre aquilo que o professor fala e aquilo que ele pratica. Sua prática deve testemunhar as suas afirmações, redizendo - ao invés de desdizer - suas argumentações. Esse aspecto é de grande importância à constituição da autonomia (tanto de educadores quanto de educandos), visto que os sujeitos devem ter clareza acerca de como suas ações lhes representam.

Freire sugere que onde há vida há inacabamento, sendo que ao expressar que "Ensinar exige consciência do inacabamento", o estudioso se remete à visão do ser humano como sujeito cultural e histórico, que deve ser consciente dessa sua condição de inacabado. Ele frisa que a história que se faz, em conjunto com os outros, é um tempo de possibilidades e não de determinismo. A ideia do inacabamento faz-se importante à dinâmica renovadora da formação da autonomia docente, levando o professor a buscar sempre novos subsídios epistemológicos à sua prática educativa, bem como tornando-lhe consciente acerca do potencial transformador de suas ações.

Baseado sempre por uma postura ética, Freire enfatiza a importância de se respeitar a autonomia do ser do educando (independente do ser criança, jovem ou adulto), bem como o educador deve se respeitar, igualmente, em sua própria autonomia. A ética sugere que sujeitos dialógicos aprendam e cresçam na diferença e, sobretudo, no respeito a ela. Diante disso, concorda-se com o autor quando friza que "Ensinar exige respeito à autonomia do ser do educando", pois também se valoriza a ideia de que o respeito (tanto à autonomia quanto à dignidade humana) é um imperativo ético e não um favor que se pode ou não se conceder ao outro. Neste sentido:

O professor que desrespeita a curiosidade do educando, o seu gosto estético, a sua inquietude, a sua linguagem, mais precisamente, a sua sintaxe e a sua prosódia; o professor que ironiza o aluno, que o minimiza, que manda que 'ele se ponha em seu lugar' ao mais tênue sinal de sua rebeldia legítima, tanto quanto o professor que se exime do cumprimento do seu dever de propor limites à liberdade do aluno, que se furta ao dever de ensinar, de estar respeitosamente presente à experiência formadora do educando, transgride os princípios fundamentalmente éticos de nossa existência (FREIRE, 1996, p. 59-60). 
Evidencia-se, assim, que o professor precisa saber que deve respeito à autonomia e às singularidades do educando. O respeito, como base da relação, possibilitará o fomento e a fruição da diversidade de saberes, enriquecendo as trocas educativas.

O bom senso é um aspecto de grande importância na discussão sobre a formação de professores, uma vez que a atuação prática docente requer, a todo momento, que o professor se posicione diante das demandas cotidianas. Ele precisa do bom senso, que fortalece sua autonomia, para indagar, duvidar, comparar, decidir, intervir, escolher, ajuizar, abdicar, orientar e mediatizar grande parte das situações práticas do seu dia a dia profissional. Sobre esse aspecto Freire cita que "Ensinar exige bom senso", uma vez que essa condição humana deve ser a bússola norteadora da prática educativa. Nesta direção, afirma o autor:

É o meu bom senso que me adverte de que exercer minha autoridade de professor na classe, tomando decisões, orientando atividades, estabelecendo tarefas, cobrando a produção individual e coletiva do grupo não é sinal de autoritarismo de minha parte. É minha autoridade cumprindo o seu dever (FREIRE, 1996, p.61).

Corrobora-se com a afirmação do autor ao acreditar-se que o bom senso é uma postura ética de grande valor à formação da autonomia, pois o exercício do bom senso leva à superação do que há de instintivo na avaliação que se faz dos fatos e acontecimentos.

É evidente na concepção de Freire que a prática educativa demanda da existência de sujeitos - um que, ensinando, aprende e outro que, aprendendo, ensina - sendo que nessa dinâmica o professor deve ter muita clareza acerca das diferentes dimensões que fundamentam a essência de sua prática. É sobre esse aspecto a que se refere Freire ao indicar que "Ensinar exige apreensão da realidade", vista como a capacidade para aprender (não apenas com o fim de adaptação), intervir, transformar, recriar a realidade. Neste sentido, Freire (1996, p. 69) afirma que "A nossa capacidade de aprender, de que decorre a de ensinar, sugere ou, mais do que isso, implica a nossa habilidade de apreender a substantividade do objeto aprendido". Apreendendo a realidade o professor, certamente, mobilizará recursos mais consistentes ao fomento de sua autonomia, enriquecendo sua prática educativa.

A apreensão da realidade enquanto crescente conscientização acerca da mesma, apresenta-se coerente com o que Freire mensiona sobre "Ensinar exige a convicção de que a mudança é possível”, pois o futuro não é inexorável e ao problematizá-lo o professor vislumbra as possibilidades de mudança que ele apresenta. Educador e educando devem ter a convicção de que suas ações não são neutras, mas que interferem na objetividade do mundo. Seus papéis transcendem a constatação do ocorrido, tornando-lhes sujeitos de ocorrências. Essa convicção aumenta, logicamente, a 
responsabilidade de cada um. Entretanto, não há como se pensar em autonomia sem ligá-la à responsabilização da qual não se desprende.

Ao debruçar-se sobre a constituição da autonomia docente, não há como deixar de se remeter ao fato de que "Ensinar exige comprometimento", pois como cita Freire (1996, p. 92) "O professor que não leve a sério a sua formação, que não estude, que não se esforce para estar à altura de sua tarefa não tem força moral para coordenar as atividades de sua classe”. Corroborando com as ideias do autor - que ao se manifestar acerca desse comprometimento o faz sem afirmar que a qualidade da prática docente seja determinada, exclusivamente, pela competência científica do professor acredita-se que a incompetência profissional, certamente, desqualifica a ação educativa. Isso não quer dizer, entretanto, que o professor precisa saber tudo. Se diante de uma pergunta, cuja resposta não conheça, ele se assume como alguém que não sabe, mas que pode vir a saber, esse professor demonstra humildade, humanidade, inacabamento e senso de pesquisa. Essas características são importantes e constitutivas da formação docente.

Entretanto, para dirimir o processo de ensino o prefessor precisa conhecer o objeto cognoscível, bem como conhecer os caminhos da aprendizagem, dominando as possibilidades que estes oferecem ao seu trabalho. Precisa, ainda, ter consciência crítica de suas escolhas, sabendo que não existe neutralidade em sua prática. Bem como deve saber buscar a aproximação entre o que diz e o que faz, entre o que aparenta e o que é. Para tanto, o professor precisa ter a sua autonomia fundamentada na sua responsabilidade e no seu comprometimento.

A educação - sendo um ato eminentemente humano, dialético e contraditório - culmina em resultados. Sendo que, enquanto partícipe do processo de formação humana, cabe ao professor refletir acerca dos resultados de suas ações pedagógicas, atentando ao que está produzindo e/ou reproduzindo. Neste sentido, concordamos com Freire quando afirma que "Ensinar exige reconhecer que a educação é ideológica", pois estar atento às armadilhas sorrateiras da ideologia é uma necessidade visceral ao educador, já que ela - ao penumbrar, opacizar ou ocultar a realidade dos fatos - afeta a visão crítica necessária ao ato transformador. A esse respeito o autor frisa que:

No exercício crítico de minha resistência ao poder manhoso da ideologia, vou gerando certas qualidades que vão virando sabedoria indispensável à minha prática docente. A necessidade desta resistência crítica, por exemplo, me predispõe, de um lado, a uma atitude sempre aberta aos demais, aos dados da realidade; de outro, a uma desconfiança metódica que me defende de tornar-me absolutamente certo das certezas. Para me resguardar das artimanhas da ideologia não posso nem devo me fechar aos outros nem tampouco me enclausurar no ciclo de minha verdade. Pelo contrário, o melhor caminho para guardar viva e desperta a minha capacidade de pensar certo, de ver com acuidade, de ouvir com respeito, por isso de forma exigente, 
é me deixar exposto às diferenças, é recusar posições dogmáticas, em que me admita como proprietário da verdade (FREIRE, 1996, p. 133-134).

Assim, reitera-se a exposição de Freire, pois um ato educativo que vislumbra a autonomia deve reconhecer o poder persuasivo da ideologia, considerando sua constante tentativa de anestesiar mentes, confundir curiosidades, distorcer percepções e difundir "verdades absolutas". Muitas vezes ela cega e ensurdece a ponto de levar à aceitação dócil, passiva e incontestável de situações extremamente injustas e absurdas. Além de corromper os nossos sentidos, ela tem poder letal: mata sonhos, perspectivas, esperanças e utopias.

Sabe-se que a autonomia é um ato, genericamente, dialógico que se faz mais na relação com o outro do que no cerne individual, solitário. Neste sentido, coadunamos com a afirmação de Freire quando enfatiza que "Ensinar exige disponibilidade para o diálogo", uma vez que ao nos disponibilizarmos a dialogar abrimos caminhos à aceitação, à flexibilidade das razões, ao contato com o outro ("igual" ou "diferente"), ao respeito, à empatia.

Segundo Freire (1996, p. 135), "Minha segurança se funda na convicção de que sei algo e de que ignoro algo a que se junta a certeza de que posso saber melhor o que já sei e conhecer o que ainda não sei”. A assertiva anuncia que a disponibilidade ao diálogo supõe a consideração do novo, mas também requer segurança ao discutir um tema, analisar um fato, esboçar um posicionamento, ainda que este retrate o desconhecimento de algo para o qual se buscará as possíveis respostas.

Dialogar com o educando e com sua realidade é condição imprescindível à efetivação do ato educativo. Assim, o professor precisa se tornar cada vez menos estranho aos olhares e vivências materiais, afetivas, sociais, econômicas e culturais dos educandos e, sem dúvida, o diálogo é um meio importante ao estreitamento das distâncias que, muitas vezes, afastam abissalmente esses dois sujeitos. Não há construção da autonomia sem diálogo, não há educação sem diálogo.

\section{A AUTONOMIA COMO CONSTRUÇÃO ALICERÇADA NA CONSCIÊNCIA CRÍTICA DOCENTE}

Não é difícil perceber situações em que o senso comum, lamentavelmente, expressa uma banalização do fazer docente, tornando a atividade do professor um ato sobre o qual qualquer um pode opinar e, o que é mais grave, deliberar decisões conclusivas e, muitas vezes, errôneas. Assim, é corriqueiro se tecer "comentários" de que as pessoas não se arriscam a opinar, por exemplo, sobre a atuação profissional de um médico ou de um advogado tais como o fazem diante da atuação do professor. Esse tipo de posicionamento, culturalmente alicerçado, relaciona-se intimamente com os 
saberes e a autonomia docentes e só poderá ser combatido a partir de uma formação inicial e continuada comprometida com a compreensão e o fomento crítico desses elementos, pois como expõe Contreras:

\begin{abstract}
Ninguém pode assumir pelo professor o juízo e a decisão diante das situações que requerem uma atuação em sala de aula. O docente se vê obrigado a assumir, por si só, um compromisso pessoal com os casos concretos, a atuar em função de suas próprias interpretações, conviçcões e capacidades. Esse fato indica tanto a necessidade e a inevitabilidade do juízo moral autônomo, como a impossibilidade, em muitas ocasiões, de um tempo para meditar ou para consultar e compartilhar responsabilidades (CONTRERAS, 2002, p. 195-196).
\end{abstract}

Para o autor, ninguém deve substituir o que, em última instância, decide um professor em sua classe, sendo que esse posicionamento é imbuído de uma gama expressiva de responsabilidade por parte desse profissional. Ele deve buscar condições para transpor as impossibilidades, refletindo sobre suas condições de trabalho e existência, sendo que o compartilhar de responsabilidades, com seus pares laborais, é uma condição importante para que sua prática seja desenvolvida adequadamente.

Considerando a importância da vivência dialogal com a realidade, entende-se a autonomia como um exercício de intervenção fundamental no mundo, um elemento crítico na formação do professor. Ela pode ser interpretada como um instrumento para obter mais espaços de interdependência em decisões docentes, diminuindo o controle burocrático por parte das administrações públicas, bem como pode fazer-se como recurso transformador das intervenções externas (como família e sociedade) comuns na prática educativa formal.

Os professores ocupam uma posição fundamental no dia a dia escolar. Assim, ressaltamos a importância desse profissional, concordando com a exposição de Tardif (2014, p. 228) "“[...] em seu trabalho cotidiano com os alunos, são eles os principais atores e mediadores da cultura e dos saberes escolares. Em suma, é sobre os ombros deles que repousa, no fim das contas, a missão educativa da escola". Neste sentido, a autonomia dos professores deve ser fundada na consciência crítica de seus papeis para com o ato educativo. São eles quem possuem saberes específicos que são mobilizados, utilizados e produzidos no desenvolvimento do fazer profissional cotidiano, devendo se considerarem e serem considerados, por isso, sujeitos do conhecimento.

Ressalta-se que para Contreras (2002), a reivindicação da autonomia não é uma exigência trabalhista oriunda e voltada ao bem apenas dos professores, mas o é, principalmente, pelo bem da própria educação. Diante disso, esse profissional precisa ter clareza de que os processos de racionalização de seu trabalho, a separação da concepção e da execução do seu fazer pedagógico, impõe-lhe forte dependência em relação às diretrizes externas, sendo que tal dependência se traduz 
na coisificação dos valores e das pretensões educativas. Trata-se de instrumentos intencionais que moldam e engessam a ação do professor, como enfatiza Contreras:

[...] Um aumento da regulamentação prescrita da prática docente, no contexto das formas burocráticas que dominam as relações institucionais, exige necessariamente um aumento da prescrição indiscutível dos resultados para que possam agir de maneira efetiva como critérios de controle no cumprimento das referidas prescrições. Isso significa que os valores educativos, que guiam teoricamente a prática do ensino, transformam-se em condutas e resultados previstos (CONTRERAS, 2002, p. 194).

Acompanhando a linha de raciocínio, constata-se uma inversão no curso correto e natural da ação do professor, pois - ao se converterem em resultados previsíveis - os valores e pretensões que deveriam agir como orientadores internos da prática, assumem a função de orientadores externos que instrumentalizam a própria prática. Assim, a perda da autonomia dos modos de controle técnico e burocrático intensifica a perda da instrumentalização da prática. Sobre esse aspecto, Tardif propõe que:

[...] se pare de considerar os professores, por um lado, como técnicos que aplicam conhecimentos produzidos por outros (por exemplo: os pesquisadores universitários, os peritos em currículo, os funcionários do Ministério da Educação, etc.) e, por outro lado, como agentes sociais cuja a atividade é determinada exclusivamente por forças ou mecanismos sociológicos [...] (TARDIF, 2014, p. 229-230).

As considerações acima são visões redutoras do ensino e do papel do professor, condizentes com as políticas públicas, geralmente reducionistas, que não contemplam (com a necessária seriedade) muitas das questões que compõem a educação. Suas lógicas - inclinadas ao ideário capitalista - inibem o fomento do exercício do pensar e agir, ações fundamentais ao aguçar da autonomia docente.

A partir de uma chave hermenêutica crítica, concorda-se com Contreras (2002) quando afirma que a autonomia se materializa no processo de percepção dos limites e das possibilidades da atuação docente na estrutura social. Tal atuação está inter-relacionada às práticas de planejar, compreender e agir sobre a produção do conhecimento sem, contudo, isolar-se das pessoas com que se relaciona, pois é na relação com o outro e no diálogo aberto e fecundo que se constrói a própria profissionalidade.

Para o autor, a relação entre autonomia e profissionalidade é, concomitantemente, uma reivindicação da dignidade humana, das condições trabalhistas docentes e uma reivindicação de oportunidade para que a prática de ensino possua condições de se desenvolver de acordo com determinados valores educacionais (os quais não sejam coisificados e atuem como elementos 
constitutivos e orientadores da própria prática). Neste sentido, a autonomia configura-se como um direito trabalhista e como uma necessidade educativa, as quais, evidentemente, ganham força na ação coletiva. Nessa direção, Contreras enfatiza que:

[...] tanto a autonomia profissional como pessoal não se desenvolvem nem se realizam, nem são definidas pela capacidade de isolamento, pela capacidade de 'se arranjar sozinho', nem pela capacidade de evitar as influências ou as relações. A autonomia se desenvolve em um contexto de relações, não isoladamente. Tem a ver, portanto, com uma forma de manter relações (2002, p.199).

Considera-se, assim, que a autonomia, deve ser o ponto de intersecção entre o modo de agir docente e sua vivência social, a qual se constrói e realiza, respaldada pela convivência e pela experiência. Como afirma Freire (1996, p.105) “A gente vai amadurecendo todo dia, ou não. A autonomia, enquanto amadurecimento do ser para si, é processo, é vir a ser”. Neste caso, a construção da autonomia - alicerçada na consciência crítica docente - faz-se como um processo dinâmico e dialógico. Sua concretização não está em conformidade com o status quo e, portanto, trata-se de uma via delicada e conflituosa. Tal pressuposto é intrínseco às relações tensionais que se dão entre os agentes da educação, bem como desta com o poder hegemônico. Assim, ressalta-se a importância de se pensar a formação docente como instrumento de resistência e enfrentamento às instâncias da ordem social dominante.

\section{CONSIDERAÇÕES CONCLUSIVAS}

No confronto com a realidade opressora que se dá no mundo circundante, o docente deve ter (em sua vivência pedagógica) a clareza para fazer o contramovimento pela autocrítica e crítica sobre sua formação. A autonomia apresenta-se relevante nesse contramovimento, sendo que se realiza no desdobramento histórico, social, político, cultural e ideológico e não ocorre de modo imediato. Essa construção é um processo lento, imbricado em tensões entre forças de relações, que não se realiza de forma neutra, pois o ser humano, cotidianamente, está em constante interação com o mundo e com o outro.

Pode-se dizer que o fomento à autonomia remete ao exercício da liberdade: na maneira de agir, pensar e articular o projeto existencial na vida do sujeito, capaz de exercer sua razão de modo crítico nos âmbitos público e privado. Considera-se que a autonomia deve fazer-se como ponto de intersecção entre o modo de agir docente e sua vivência social. A esse respeito Freire (1996, p. 61) evidencia "[..] saber que devo respeito à autonomia e à identidade do educando exige de mim uma prática em tudo coerente com este saber". Ressalta-se que tal coerência deve evidenciar-se como um 
ato enaltecedor da autonomia de todos os envolvidos no processo educativo, principalmente, do próprio professor. Seus saberes e sua autonomia são aspectos constitutivos de sua identidade e profissionalidade e precisam ser focalizados desde a sua formação inicial.

Assim, "Saberes e autonomia docente: um diálogo entre elementos imprescindíveis à formação do professor", desvelou aspectos bastante relevantes acerca da importância dos saberes docentes como basilares à constituição da autonomia, evidenciando a necessidade de uma formação coerente com o fomento à criticidade, direcionando-se à tecitura de uma prática educativa que, de fato, dialogue com as demandas contemporâneas progressistas.

\section{REFERÊNCIAS}

CONTRERAS, José. A autonomia de professores. SP: Cortez, 2002.

FREIRE, Paulo. Pedagogia da autonomia: saberes necessários à prática educativa. SP: Paz e Terra, 1996.

RAMALHO, Betânia Leite; NUÑEZ, Isauro Beltrán. Formação, representações e saberes docentes: elementos para se pensar a profissionalização dos professores. Campinas, SP: Mercado de letras, 2014.

TARDIF, Maurice. Saberes docentes e formação profissional. 17 ed. RJ: Vozes, 2014. 
